\title{
III. kardiovaskulární česko-slovenský summit, Mikulov
}

V sobotu 17. března se konal v Mikulově již III. kardiovaskulární summit s názvem: Rozhodují komorbidity o volbě terapie? Tento česko-slovenský seminář organizačně perfektně zajistila firma Abbott a podpořila jej svým edukačním grantem. Ve spolupráci České společnosti pro hypertenzi, České internistické společnosti ČLS JEP a Českého institutu metabolického syndromu, o. p. s., byl připraven odborný program věnovaný aktuálním tématům v problematice kardiovaskulárních a renovaskulárních nemocí.

První sekci, která byla věnována arteriální hypertenzi (AH) kombinované s dalšími onemocněními, moderovala paní doc. MUDr. S. Filipová, CSc., z Bratislavy (prezidentka Slovenské hypertenziologické společnosti) a jeden z našich předních odborníků v oblasti arteriální hypertenze prof. MUDr. J. Widimský, CSC., jr., z Prahy (místopředseda České společnosti pro hypertenzi). Prof. MUDr. V. Monhart, CSc., z Prahy se věnoval renální hypertenzi, která patří mezi druhé nejčastější sekundární hypertenze. Velkou pozornost věnoval výběru léků v léčbě této hypertenze, u níž použití inhibitorů ACE a inhibitorů receptorů $A T_{1}$ pro angiotensin II (sartanů) má svoje výsostní postavení, nebot tyto léky zpomalují rozvoj renálního selhání. Názorně vysvětlil účinek různých antihypertenziv na mikrocirkulaci glomerulu; zatímco dihydropyridinové blokátory kalciového kanálu neovlivňují intraglomerulární tlak ani albuminurii, inhibitory systému renin-angiotensin (RAS) svým účinkem dilatují přívodnou i odvodnou arteriolu glomerulu, snižují intraglomerulární tlak, snižují albuminurii a zachovávají funkci glomerulu. Podobný účinek byl popsán i u non-dihydropyridinového blokátoru kalciového kanálu verapamilu SR. Na studii BENEDICT doložil, že kombinace trandolaprilu a verapamilu SR je vysoce nefroprotektivní. Diskutovalo se o otázce kombinace inhibitoru ACE se sartany u nemocných s hypertenzí a chronickým renálním onemocněním. Závěrem bylo konstatováno, že tato otázka nebyla zcela vyřešena ani studií ONTARGET a že je třeba ještě další sledování, které by mohlo u některých pacientů s renální hypertenzí prokázat prospěch z kombinované léčby inhibitorů ACE a sartanů.

Doc. MUDr. S. Krčméry, CSc., z Bratislavy přednášel o léčbě $A H$ u starších pacientů. Až $75 \%$ pacientů nad 60 let věku má $A H$, která je ve většině případů systolická nebo predominantně systolická. Seznámil posluchače s novým sartanem - eprosartanem, který kromě typických účinků sartanu má také schopnost snížit nadměrnou aktivitu sympatického nervového systému, což se zdá být velmi prospěšné nejen v léčbě samotné systolické $A H$, ale také v ovlivnění kognitivních funkcí starších nemocných. Ve studii OSCAR zlepšila léčba eprosartanem kognitivní funkce - významně vylepšila skóre použitého testu MMSET (Minimal-Mental State Examination Test). Větší zlepšení bylo patrné především u nemocných se snížením systolického krevního tlaku (sTK) $<140 \mathrm{~mm} \mathrm{Hg}$.

Prof. MUDr. J. Widimský jr., CSc., se věnoval hypertenzi a fibrilaci síní. Vyšel ve své přednášce z „position paper"
European Society of Hypertension (ESH) a z evropských doporučení pro léčbu fibrilace síní. Kombinace těchto nemocí zvyšuje riziko celkové mortality. Arteriální hypertenze je vedle věku jedním z nejčastějších rizikových faktorů vzniku fibrilace síní. $V$ léčbě $A H$ u těchto nemocných je třeba preferovat inhibitory ACE a sartany, které ovlivňují i riziko fibrilací síní. Přesto máme zatím málo dat o léčbě $A H$ u nemocných s fibrilací síní. Studie TRACE prováděná u nemocných se srdečním selháním sledovala vliv trandolaprilu a kromě jiného zjistila, že trandolapril významně snížil riziko vzniku fibrilace síní relativně o $55 \%$ ve srovnání s placebem. Také ve studii BENEDICT bylo zjištěno, že léčba trandolaprilem významně snížila riziko rozvoje hypertrofie LK a fibrilace síní. Kombinace trandolaprilu s verapamilem SR se tak zdá být potenciálně výhodná v prevenci vzniku fibrilace síní.

Prof. MUDr. L. Špinarová, CSC., připomněla ve své přednášce největší pokrok $v$ kardiologii, tj. zlepšení léčby akutního infarktu myokardu, které se podílí na prodloužení střední délky života asi třemi roky. Ve své přednášce zdůraznila význam inhibitorů $A C E v$ kombinaci s verapamilem SR u nemocných $\mathrm{S} A \mathrm{H}$ a infarktem myokardu. Připomněla studie INVEST a TRACE, SAVE, AIRE aj., ve kterých byl prokázán významný účinek inhibitorů ACE na redukci remodelace levé komory po srdečním infarktu. $U$ nemocných $s$ ischemickou chorobou srdeční se považuje za vhodný cílový systolický TK 130-140 mm Hg, přičemž by neměl klesat < $120 \mathrm{~mm} \mathrm{Hg}$ a diastolický TK by neměl klesat < $70 \mathrm{~mm} \mathrm{Hg}$.

Prof. MUDr. J. Špinar, CSc., hovořil o hypertenzi v souvislosti s cévní mozkovou příhodou. Upozornil na velký sociozdravotnický i ekonomický problém iktů, které mají daleko horší prognózu ve srovnání s infarktem myokardu. Věk a systolický TK jsou hlavními rizikovými faktory. $\mathrm{Na}$ studiích LIFE a SCOPE poukázal na skutečnost, že sartany jsou lepší než ostatní antihypertenziva v primární prevenci cévních mozkových príhod. Studie SYST-EUR prokázala nejen významné snížení relativního rizika vzniku cévních mozkových príhod u starších nemocných léčených nitrendipinem (o 42 \%), ale i snížení výskytu demence (o 55 \%), která souvisí především se systolickým TK. V sekundární prevenci iktů zmínil studii PROGRESS, v níž nevelké snížení TK mělo za následek významné snížení iktů, a studii MOSES, v níž léčba eprosartanem ve srovnání s léčbou nitrendipinem dále významně snížila kardiovaskulární morbiditu a mortalitu (o $21 \%$ ) a sekundární cílové ukazatele - cerebrovaskulární příhody (o $25 \%$ ) a kardiovaskulární příhody (o $25 \%$ ). Eprosartan v dávce 600-800 mg měl stejný antihypertenzní účinek jako nitrendipin, ale významně lepší účinek na cílové ukazatele, čehož zřejmě dosáhl i svým přímým účinkem na presynaptický receptor neuronu sympatického nervového systému.

O vegetativním nervovém systému pohovořil prof. MUDr. M. Souček, CSc., který se dlouhá léta zabývá výzkumem sympatiku a jeho vlivem na $A H$. Ve své přednášce vysvětlil strukturu a protichůdné funkce sympatického 
nervového systému a jeho vztah především ke tkáňovému RAS. Ukázal možnosti diagnostiky a léčby dysfunkce sympatiku. Zdůraznil účinky moxonidinu, který stimuluje imidazolinové receptory a pomèrně fyziologickým způsobem snižuje aktivitu sympatiku. Připomněl také studii VAMPYRE, ve které verapamil SR více snížil klidový i zátěžový TK a tepovou frekvenci a zlepšil variabilitu TK ve srovnání s amlodipinem.

Druhé části summitu předsedala prof. MUDr. H. Rosolová, DrSc., ředitelka Českého institutu metabolického syndromu, o. p. s., a prof. MUDr. R. Češka, CSc., předseda České internistické společnosti ČLS JEP. Tato sekce byla věnována metabolickému syndromu, reziduálnímu vaskulárnímu riziku a kombinované léčbě dyslipidemií. Prof. MUDr. H. Rosolová, DrSc., se věnovala otázce kardiometabolického rizika, daného vysokým normálním TK, aterogenní dyslipidemií (zvýšené triglyceridy a snížený HDL cholesterol), abdominální distribucí tukové tkáně a poruchami glukózové homeostázy. Aktivace sympatického nervového systému a RAS u těchto osob určuje výběr antihypertenziv $v$ léčbě prehypertenze $u$ nemocných s nakupenými rizikovými faktory nebo se subklinickým orgánovým poškozením, tj. inhibitorů RAS (inhibitory $A C E$, sartany), léků snižujících aktivitu sympatiku (verapamil SR, centrálně působící antihypertenziva, nové generace sartanů).

Prof. MUDr. R. Češka, CSc., hovořil o nových trendech $v$ léčbě dyslipidemií. Statiny jsou samozřejmě léky první volby $\mathrm{k}$ dosažení cílových hodnot LDL cholesterolu, ale chceme-li dosáhnout i velmi přísných cílových hodnot u nemocných s velmi vysokým kardiovaskulárním rizikem, často musíme použít kombinaci dvou i tři hypolipidemik (statin + ezetimib + niacin). Chceme-li ovlivnit lipidové spektrum komplexně, např. u aterogenní dyslipidemie, je třeba zavádět kombinační léčbu hypolipidemiky, například statin + fibrát nebo statin + niacin. Byla zdưrazněna bezpečnost, tolerance a účinnost kombinační léčby statin + fenofibrát.

Prof. MUDr. D. Pella, Ph.D., z Košic, prezident Slovenské společnosti pro aterosklerózu, ve své přednášce hovořil o reziduálním vaskulárním riziku, které existuje u nemocných správně léčených statiny, antihypertenzivy, př́padně i antidiabetiky, a o současném postavení fibrátů v léčbě dyslipidemií. Fenofibrát významně snižuje koncentraci triglyceridů (v průměru o více než 40 \%) a zvyšuje koncentraci HDL cholesterolu (v průměru o $20 \%$ ) a zvyšuje podíl velkých LDL částic na úkor malých, což je právě nejdůležitější v ovlivnění aterogenní dyslipidemie. Rozebral studie FIELD a ACCORD a vysvětlil nevhodný výběr pacientů do těchto studií, kteří většinou neměli přítomnou aterogenní dyslipidemii, a proto primární cílové ukazatele těchto studií nebyly významně ovlivněny. Zdůraznil i pleiotropní účinky fibrátů a jejich důležitý vliv na mikrocirkulaci, zánět, steatózu jater a prevenci akutní pankreatitidy.

Závěrečnou přednášku měl MUDr. J. Pitha, CSc., vedoucí Laboratoře pro výzkum aterosklerózy IKEM Praha, který shrnul nejnovější poznatky $v$ aterosklerotickém procesu a upozornil na důležitost kombinace hypolipidemik. Představil novou lékovou formu fenofibrátu - nanoformu Lipanthyl NT 145 mg. Jeho výhodou je lepší rozpustnost a vyšší biologická dostupnost při použití nalačno i po jídle; nanokrystaly jsou 20krát menší, jejich velikost je menší než 400 nm, což zajištuje i jejich lepší účinnost a vyšší compliance pacientů. Zmínil se také o vývoji nových hypolipidemik, jako jsou inhibitory LCAT, apo-A1 mimetika aj.

Symposium probíhalo v Mikulově $v$ hotelu Galant a účastnilo se jej více než 450 lékařủ z Česka a Slovenska. Přestože počasí bylo venku nádherné a lákalo na procházku po Mikulově a jeho okolí, přednáškový sál byl stále plný a po každé přednášce se rozpoutala živá diskuse, kterou se předsedajícím ne vždy podařilo dưsledně časově usměrnit. Nikdo se však nehněval, protože všichni byli díky zajímavému programu dobře naladěni.

Prof. MUDr. Hana Rosolová, DrSc., Centrum preventivní kardiologie, II. interní klinika, Univerzita Karlova Praha - Lékařská fakulta v Plzni a Fakultní nemocnice Plzeň, Plzeň, e-mail: rosolova@fnplzen.cz 